\section{Mass transfer of aluminum film from the surface of zeolite on the cathode}

N. N. LEBEDEVA - Institute for Problems, Baku State University - nnlebedeva@gmail.com

V. I. ORBUKH - Institute for Problems, Baku State University - orbukh@ramblero.ru

G. M. EYVAZOVA - Institute for Problems, Baku State University - eygoncha@mail.com

N. H. DARVISHOV - Institute for Problems, Baku State University - n_darvishov@mail.ru

CH. G. AKHUNDOV - Institute for Problems, Baku State University - ch.axundov@mail.ru

Érkezett: 2018. 04. 17. - Received: 17. 04. 2018. - https://doi.org/10.14382/epitoanyag-jsbcm.2018.22

\section{Abstract}

In the present study, the phenomenon of mass transfer of an aluminum film deposited on the zeolite surface onto a clamping electrode was observed. The proposed four-layer model explains the very fact of mass transfer (inhomogeneous over the cross section of the structure) in the absence of anomalously large electric fields at the cathode.

Keywords: zeolite, mass transfer, clinoptilolite, zeolite pores, zeolite framework

Kulcsszavak: zeolit, tömegáram, klinoptilolit, zeolit pórusok, zeolit vázszerkezet

Nelli N. LEBEDEVA

Graduated at Baku State University in 1960 with a specialty in Physics of Semiconductors and Dielectrics. Field of interests: physical phenomena inhomogeneous system 1) ferroelectrics-semiconductor; 2) photoconductors-plasma of a gas discharge; 3) dielectrics (zeolites) -conductors (graphite, silicon, Ag, Cu)

Vladimir I. ORBUKH Graduated at Baku State University in 1971 with a specialty in Physics of Semiconductors and Dielectrics. Field of interests: theory of physical phenomena inhomogeneous system 1) ferroelectrics-semiconductor; 2 photoconductors- plasma of a gas discharge: 3) dielectrics (zeolites) -conductors (graphite, silicon, Ag, Cu

Goncha M. EYVAZOVA

Graduated at Baku State University (BSU) department of Physics in 1974. Completed her $\mathrm{PhD}$ degree under the supervision of Prof. A. M. Mamedov at BSU. Now she is leading scientific researcher in Nano Center, Department of Physics, BSU. Her current research interests include the synthesis of nanostructured metal chalcogenides, various nanoparticles, and investigation of optical and electrical properties.

Namiq H. DARVISHOV Graduated at Baku State University in 1974 with a specialty in Physics of Semiconductors and Dielectrics. Field of interests: 1) optical; 2) ferroelectrics-semiconductor; 3) photoconductorsplasma

Chingiz G. AKHUNDOV Graduated at Baku State University in 1976 with a specialty in Physics of Semiconductors and Dielectrics. Field of interests: physical phenomena inhomogeneous system 1) ferroelectricssemiconductor; 2) photoconductors-plasma of a gas discharge; 3) dielectrics (zeolites) conductors (graphite, silicon, Ag, Cu)

\section{Introduction}

Zeolites are aqueous aluminosilicates, the infinite aluminosilicate frame of which is formed by the joint of the common vertices of $\left[\mathrm{SiO}_{4}\right]^{4}$ and $\left[\mathrm{AlO}_{4}\right]^{5}$ tetrahedra, having interconnected cavities occupied by large ions and water molecules [1]. The loosely bound cations and water molecules in the pores of the zeolites are characterized by considerable mobility, which allows ion exchange and reversibility of the dehydration without affecting the aluminosilicate rigid framework. Due to this property zeolites have extremely wide scope of use in industry and agriculture.

Currently, more than 45 types of natural zeolites are known, of which the most common are clinoptilolite, heylandite, phillipsite, lomonite, mordenite, erionite, chabazite, ferrierite, analcime. Clinoptilolite is defined as a series of zeolitic minerals having a clear structural topology of heylandite (HEU) and a $\mathrm{Si} / \mathrm{Al}$ ratio of 4.0 .

The structural topology of the tetrahedral HEU lattice has been extensively studied and has a C2/m symmetry with oblate channels bounded by ten-membered channels $(7.5 \times 3.1 \mathrm{~A})$ and eight-membered tetrahedral rings $(4.6 \times 3.6 \mathrm{~A})$ parallel to the $\mathrm{C}$ axis. The additional eight-membered circular channels $(4.7 \times 2.8 \mathrm{~A})$ are parallel [100] and [102] and intersect with the preceding channels within [010], forming a system of twodimensional parallel channels to [010], which are responsible for the layered structure $[1,2]$.
Analysis of data on the structure and properties allows us to consider this zeolite not only as a promising sorbent, but also as an object on which it is possible to investigate poroemission of electrons, electron multiplication and gas discharge in pores [3], dielectric and electrical properties [4]. If the sorption properties of the zeolite are determined by the size and configuration of the pores, then its electrical properties are determined by the composition of the substance in the pore space [5]. On the basis of X-ray and spectral chemical analysis, we established that the natural zeolite we are studying belongs to high-silica zeolites of the clinoptilolite type [6]. The content of the channels, which is an off-frame subsystem, is positively charged $\mathrm{Na}+, \mathrm{K}+, \mathrm{Mg}+, \mathrm{Ca}+$ ions that compensate for the negative charge of the framework, as well as a large number of molecules of $\mathrm{H}_{2} \mathrm{O}$-coordination water.

Water plays an important role in ensuring the stability of the clinoptilolite framework and, as suggested, leads to an increase in the mobility of ions in the pore space. Loosely bound cations and water molecules in pores of zeolites lead to high values of the dielectric constant at low frequencies and a significant dependence of the electrophysical properties of seolites on frequency and temperature. The ability of cations to diffuse through a large open zeolite structure makes it possible to obtain high ionic conductivity in zeolites. In recent years, many attempts have been made to investigate the factors that control ion transport in an external electric field [7]. These 

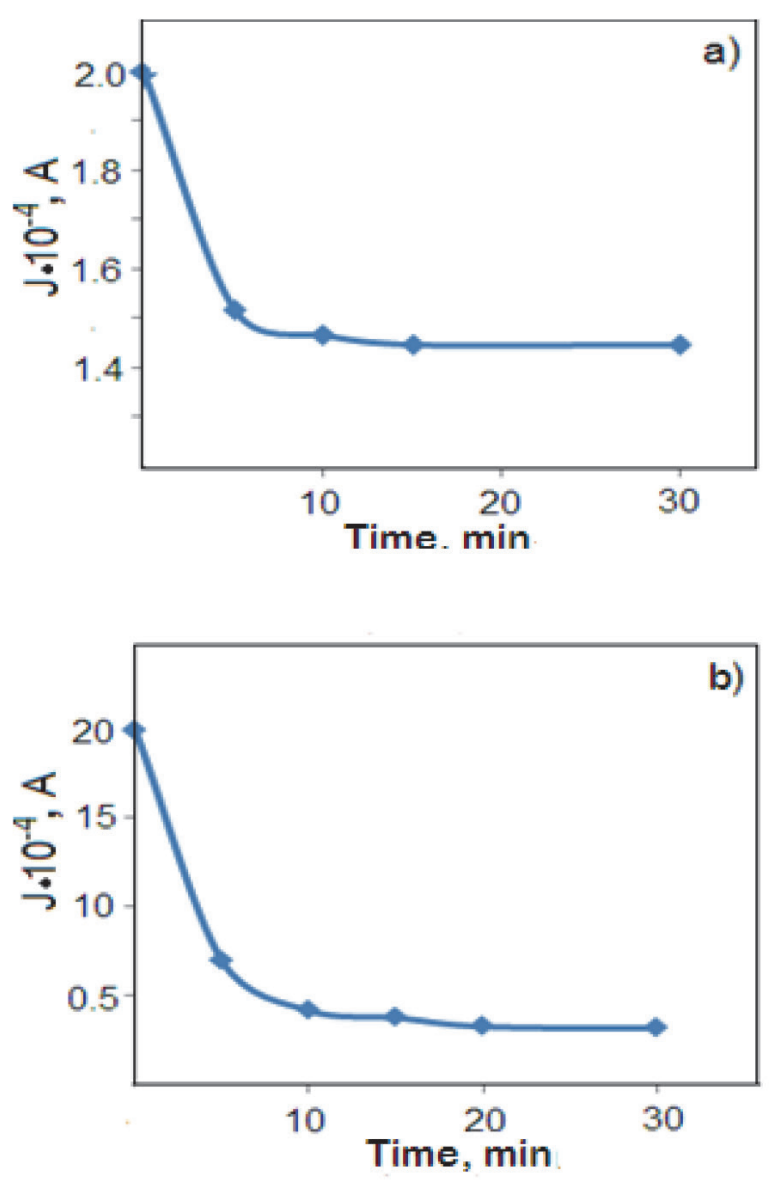

Fig. 1. The time dependence of the current at a negative (a) and a positive (b) electrode potential

1. ábra Áramerösség időfüggése (a) negativ és (b) pozitív elektródpotenciál esetén

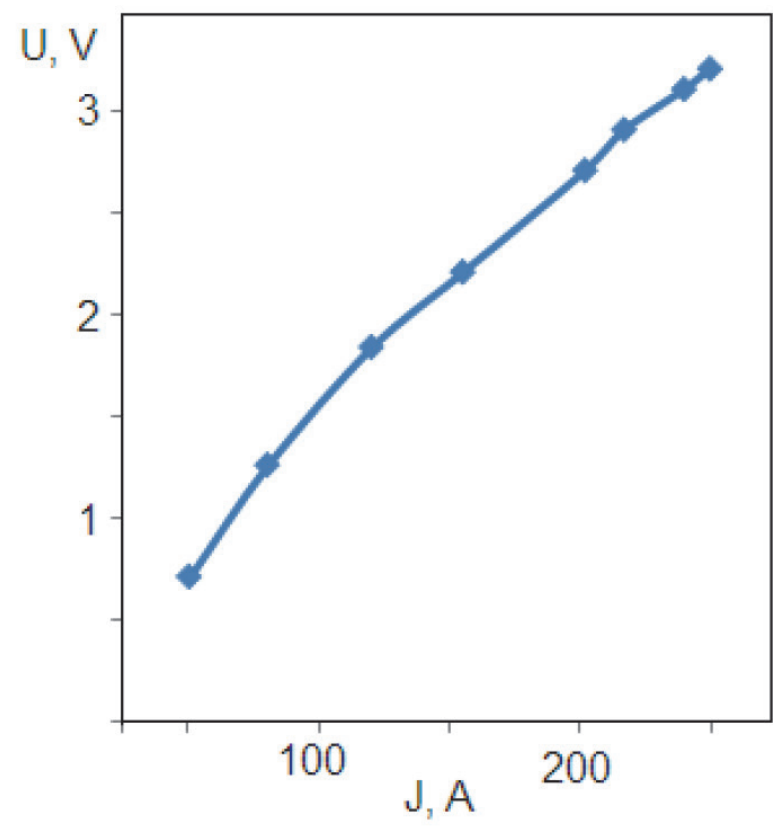

Fig. 2. The current-voltage characteristic of a plate with aluminum sputtered on one side

2. ábra Áramerősség-feszültség karakterisztika egy oldalán alumíniummal bevont lemez esetén studies are focused mainly on the effect of temperature, the degree of hydration, the nature of the metallic cations on the conductivity, measured at alternating voltage.

In the present work, a mass transfer of a metal film deposited on the surface of a plate of natural zeolite to a negatively charged electrode is observed when a sufficiently weak constant electric field is applied.

The processes of mass transfer in the electrode-sample contact take place during welding, when the welding current is turned on, as the pre-electrode region of the heating is heated, the plastic deformation resistance decreases, respectively, the actual contact areas expand and the processes of mutual diffusion of metals develop. The mass transfer rate is controlled by the temperature in contact, the residence time of metals at elevated temperatures, the state of the surfaces of parts and electrodes, and the physical properties of the metals to be welded.

Another mechanism of, mass transfer is field desorption and field ionization [8]. The desorption theory and field evaporation consider the case of emission of positive ions in a strong electric field. Theoretical estimates of the desorption intensity for various metals are in the range $1428-288 \mathrm{Mv} / \mathrm{sm}$.

All the above conditions are not implemented in our case.

Materials: The natural zeolite clinoptilolite was used as an object of study: syngonia-monoclinic, space symmetry group $\mathrm{C} 2 / \mathrm{m}$; the unit cell parameters: $\mathrm{a}=1.761, \mathrm{~b}=1.780, \mathrm{c}=0.741$ $\mathrm{nm}, \beta=115.2^{\circ}$. For the experiment from a bulk monoblock of natural zeolite clinoptilolite, the chemical composition of which, confirmed by the X-ray analysis, contained: $\mathrm{Al}_{2} \mathrm{O}_{3}$ 11.36, $\mathrm{SiO}_{2}-67.84, \mathrm{Na}_{2} \mathrm{O}-1.25, \mathrm{MgO}-0.49, \mathrm{P}_{2} \mathrm{O}_{5}-0.11, \mathrm{SO}_{3}$ $-0.03, \mathrm{~K}_{2} \mathrm{O}-3.01, \mathrm{CaO}-0.29, \mathrm{TiO}_{2}-0.08, \mathrm{MnO}-0.078, \mathrm{Fe}_{2} \mathrm{O}_{3}-$ $1.19, \mathrm{KJ}-11.64$, the plates with the size $(15 \times 10 \times 2) 10^{-3}$ were cut. Thermal sputtering of aluminum on the ground surface $(15 \times 10)$ of a $10^{-3} \mathrm{sm}$ zeolite plate was carried out in VUP in a vacuum of $10^{-3}$ torr.

\section{Measurements}

The plate with aluminum deposited on one side was placed in a cassette, where it was clamped between two polished copper electrodes. The electrodes were supplied with a constant voltage $(\mathrm{U}=250 \mathrm{~V})$. The time dependence of the current was measured when the electrode pressed to aluminum was a cathode (Fig. 1.a) and an anode (Fig. 1.b).

In both polarities, the currents slowly decrease with time and after 30 minutes they reach saturation. After achieving a stable current $\left(10^{-4} \mathrm{~A}\right)$, the I-V characteristic was measured (Fig. 2).

\section{Discussion}

It was found that as a result of the current passing through the zeolite plate, the aluminum film on its surface can pass to the electrode. Such an aluminum mass transfer occurs only when the electrode is a cathode. It is important to note that the transfer of aluminum to the clamping electrode is not carried out over the entire area of the film. To explain the observed phenomenon, we will start from the four-layer model: a zeolite plate-an aluminum film on it-a thin air gap-a clamping 
electrode. The conductivity of the zeolite is carried out by positive ions moving in the pores of zeolite. In our model, the zeolite ions, moving toward the cathode, fall on the surface of the aluminum film, where they are neutralized due to the metallic conductivity of aluminum. Simultaneously, on the opposite side of the film (from the side of the air gap) the same positive charge arises. In other words, the charge of positive ions of the zeolite that have approached the aluminum film is converted to the same positive charge of aluminum ions on the opposite side of the film. The next stage is the recombination of these positive aluminum ions with electrons from the clamping cathode. This can happen in two ways: either electrons from the clamping electrode will transfer to the surface of the aluminum film, or positive ions of aluminum will transfer to the clamping electrode. The first of these mechanisms is more traditional and is realized when the metal film is a structure close to a single crystal, which provides a high binding energy of the ion with the film. The second mechanism is realized in the case of strongly amorphous films, which are disordered agglomerates with low binding energy of the ion with film. Such films are formed in those cases when the film is deposited on a non-crystalline (and, in general, unordered) surface. In our case, this is exactly the case, as can be seen from Fig. 3, which presents a photograph of the surface of the zeolite plate on which aluminum was deposited.

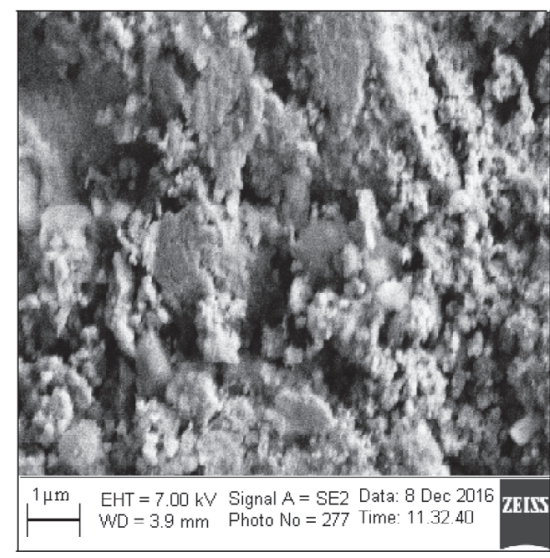

Fig. 3. Morphology of the surface of the zeolite plate

3. ábra Zeolit lemez felületi morfológiája

\section{Conclusions}

In this paper we show the possibility of mass transfer in the absence of anomalously large electric fields. This is possible due to the large positive charge on the metal amorphous film, which arise, from the neutralization of positive ions of the zeolite.

\section{Acknowledgments}

The authors wish to thank Prof. Dr. Amirullah M. Mamedov (Bilkent University) for helpful discussion and reading the manuscript.

\section{References}

[1] Gollardi, G. - Galli, E. (1985): NaturalZeolites. Springer-Verlag, Berlin, 409 p.

[2] Baerlocher, C. - Meier, W. M. - Oslon, D. H. (2001): Atlas of Zeolite Flamework Types. Amsterdam, Elsevier, 302 p.

[3] Lebedeva, N. N. - Orbukh, V. I. - Sultanov, C. A. (2010): Gas-discharge system with a zeolite electrode Technical Physics. Vol. 55, No. 4, pp. 565568. https://doi.org/10.1134/S1063784210040225

[4] Baryshnikov, S. V. - Lankin, S. V. - Stukova, E. V. - Yurkov, V. V. (2004): Conductivity of ion-replaced forms of clinoptilolite. Sovremenniye Naukoemkiye Tehnologii, Vol. 6, pp. 26-27.

[5] Bogomolov, V. N. (1978): Physcs-Uspekhi, (in Russian), Vol. 124, pp. 171.

[6] Kuliyeva, T. Z. - Lebedeva, N. N. - Orbukh, V. I. - Sultanov, Ch. A. (2009): Fizik, (in Russian) Vol. XV, No.3, pp. 43-45.

[7] Kalogeras, J. M. - Vassilikou-Dova, A. (1996): Molecular Mobility in Microporous Architectures: Conductivity and Dielectric Relaxation Phenomena in Natural and Synthetic Zeolites. Crystal Research \& Technology. Vol.31, No.6, pp. 693-726. https://doi.org/10.1002/crat.2170310602

[8] Muller, E. V. (1987): Auto ionization and auto ionic microscopy, PhysicsUspekhi, (in Russian) Vol. LXXVII, c. 3, 1062, pp. 481-551.

$\underline{\text { Ref.: }}$

Lebedeva, N. N. - Orbukh, V. I. - Eyvazova, G. M. - Darvishov, N. H. - Akhundov, Ch.G.: Mass transfer of aluminum film from the surface of zeolite on the cathode Építöanyag - Journal of Silicate Based and Composite Materials, Vol. 70, No. 4 (2018), 120-122. p. https://doi.org/10.14382/epitoanyag-jsbcm.2018.22

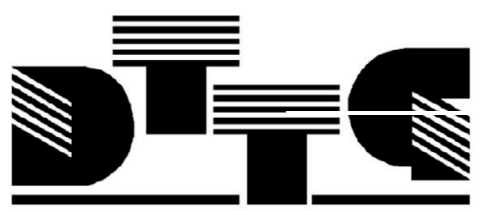

UNIVERSITÄT GREIFSWALD Wissen lockt. Seit 1450

Workshop

\section{Qualitative and Quantitative Analysis of Clays and Clay Minerals}

Inst. of Geography und Geology, University of Greifswald, Germany

18.02.-22.02.2019

organized by Georg Grathoff and Laurence Warr (Grathoff@uni-greifswald.de) 